\title{
Employing Reciprocal Teaching to Overcome Learners' Barriers to Effective Listening
}

\author{
Hesti Rokhaniyah ${ }^{1}$, Shoffin Nahwa Utama², \& Nurhana Marantika ${ }^{3}$ \\ hesti.r@unida.gontor.ac.id \\ University of Darussalam Gontor, Ponorogo, Indonesia
}

Received: 11 March 2020 Accepted: 29 May 2020

DOI: 10.24256/ideas.v8i1.1259

\begin{abstract}
The research is the action research aimed at investigating to what extent Reciprocal Teaching overcomes learners' barriers to effective listening and identifying the situation of teaching and learning when Reciprocal Teaching is employed. Several techniques: interview, observation, and test were applied to obtain the data. The mean score of two raters was calculated to derive the qualitative data; Constant Comparative Method was implemented to analyze the qualitative data. The research result showed Reciprocal Teaching implementation could overcome learners' barrier to listening including detecting the keywords; recognizing grammar and vocabularies; and discriminating distinctive sounds. The enhancement of Reciprocal Teaching illustrated form mean score of pre-test was 37.4; post-test 1 was 70.4; and post-test 2 was 81 . The use of Reciprocal Teaching also optimized the class situation: learners felt encouraged to be receptive to communication in active listening; they got freedom to mind their ideas; and they were more engaged to do mutual task. Considering the finding of the research, the lectures are recommended to use this research for guiding heir learners to solve listening barrier through Reciprocal Teaching.
\end{abstract}

Keywords: Barriers; Listening; Reciprocal Teaching

\section{Introduction}

The essence of listening was long recognized in English Language Teaching's history. Picard \& Velautham (2016) defined that the emphasis of listening started in 1800s using Direct Method and it was continued by Audio-lingual Method in which language was delivered orally prior to being presented in written communication. Given the research finding and methodological focusing on listening, the most commonly offered rationale for 
listening was teaching listening difficulty in large classes with almost no logistical support. The barrier existing in listening process for students in the university, two kinds of reasons were underscored in this paper: linguistic and non-linguistic problem. The obstacles consisted of detecting key words to obtain main idea, shortage of vocabulary, grammatical problem, and weak listening to discriminate among sounds

Some learners often disobey the goal of listening. According to the empirical research, $31.2 \%$ of the learners preferred to comprehend every word and sentence during listening test (Hui \& Susilohadi, 2011). The method they should employ depended on what questions they needed to answer. In contrast, learners rarely paid attention to the connection between sentences and their relationship. Thus, they get difficulty to grasp the keyword together with the listening content. This habit wasted their time and badly affected listening comprehension. So, weak listening skill was also responsible for listening obstruction (Ismail, Ahmadi, \& Gilakjani, 2012)

Lexical resources or words were the basis of learning language. A little knowledge of vocabulary also weakened learners' listening ability. Based on the learners' opinion, they were unfamiliar with the blank word. Therefore, they only guessed the answer increasing the mistake. On the other side, learners paid less attention to the recitation of words, which definitely had negative impact on their listening ability. Thus, shortage of vocabulary was one of the reasons for listening barrier (Lestari \& Sukirlan, 2016)

Learner with poor at grammatical structure was also considered as a big barrier during listening. For example in listening test: write no more than three words question "it can destroy the ecosystem". The blank word "destroy is very simple, yet 27 students wrote "destroying" instead of "destroy". If learners understood the grammatical aspect for this sentence (there was a word "can" in front of the missing word), their mistake might be avoided. Another example was the sentence "snoring happens when the air flow through the nose and the mouth is physically obstructed", in which the correct answer rate of the word "physically" was only $48 \%$. Disobeying the grammatical structure, many learners wrote adjective form rather than adverb form.

A large proportion of university students got difficulty to discriminate among sounds and to distinguish different pronunciation between British and American English. Even though listening vocabularies were easier than reading vocabularies, learners still could not get better understanding the listening material due to voice disturbance. In one of the listening tests, the correct answer rate of fill in the blank question: the point to notice was never made sense, it was only 47.61. A large percentage of learners filling in the word "note" were as they ignored the liaison of "notice" and "was".

Based on the condition distracting the learning process, employing strategy can bring the fresh class situation. Reciprocal Teaching can be effective for overcoming the barriers. Reciprocal Teaching method had been developed by 
(Pallinscar \& Brown, 1989). The method implemented four activities of self-directed summarizing, questioning, clarifying, predicting in the context of dialogue between teacher and learner. AlSaraireh \& Hamid (2016) also assumed that Reciprocal Teaching was as a dialogue between teacher and learners with the goals placed in of constructing meaning. Similarly, according to Ismail et al., (2012), Reciprocal Teaching was a cooperative learning instructional method employing natural dialogue models to reveal learners' thinking process of a shared learning experience. Hence, it can be summed up that Reciprocal Teaching is an instructional method which employs four activities including summarizing, questioning, clarifying, and predicting in the form of dialogue between learners and teacher during actual listening activities.

Previous researches showed that Reciprocal Teaching was an effective method to reading comprehension learning. In contrast, this method is rarely implemented to teach listening comprehension. Thus, this research is undertaken to know to what extent Reciprocal Teaching overcomes the students' barriers to effective listening and class situation when Reciprocal Teaching is applied in listening class.

\section{Method}

Action research participatory was implemented as a mode of inquiry to this study as it was a method in practical action to solve immediate problems and to develop theory (Tamura, 2006). This research had engaged learners from International Relation Department of one university in Ponorogo as they identified listening as a challenge for their disciplinary community. Two cycles were developed in this study. Lestari (2016) defined that each cycle of participatory action research consisted of (1) identification of the issue; (2) implementation of initial intervention strategy; (3) result evaluation; (4) expansion and refinement; (5) action research cycle development.

Quantitative and qualitative data were implemented in this study. Quantitative data were obtained from learners' listening scores from the beginning to the end of the cycle. On the other hand, qualitative data were collected through questionnaires, interview, and field note of observation. The pre-test as well as post-test were carried out for quantitative data. Both of the tests were then processed in order to obtain the average scores and percentages. To assess learners' ability in listening, researcher used analytic assessment as each element was evaluated separately. However, sentences and words were also needed to describe qualitative data for summing up the brief conclusions. The technique of data analysis in this research used the Constant Compare Method as suggested by Glasser (1980) as quoted by Hopkins (1993). The Comparative Constant Method was composed of the following steps: (1) comparing the events that apply to each category, 2) integrating the characteristics and categories, 3) confining the theory, and (4) constructing the theory. 
Hesti Rokhaniyah, Shoffin Nahwa Utama, \& Nurhana Marantika

Employing Reciprocal Teaching to Overcome Learners' Barriers to Effective listening

\section{Results}

Listening is difficult to learn as it is least explicit among four language skills. Psychological and cognitive processes at different level are involved to contextual and coded acoustic clues (Picard \& Velautham, 2016). Failure is the basic level which leads to a loss of confidence and to belief that listening is very difficult skill as the native speakers speak too fast. This barrier makes learners lose track of passage meaning; hence, they could not understand what the passage contains. To cope the failure in listening comprehension, proficient listener automatically uses some methods to tackle it. Reciprocal Teaching is one of many methods for explicit instruction (Rodli \& Prastyo, 2017). This method encourages a group of students to interact with the lecturer for constructing meaning and building understanding from passages.

The learners' barriers to effective listening could be minimized after Reciprocal Teaching had been implemented in learning. The findings of Reciprocal Teaching implementation were categorized into two main points as follows: (1) Reciprocal Teaching could overcome learners barriers to effective listening and (2) Reciprocal Teaching could affect the class situation. It was quite essential for learners to be accustomed to Reciprocal Teaching into foreign language learning. Reciprocal Teaching also played an important role to stimulate the basic sense such as listening and speaking and made the learners more active during the class. Likewise, it also increased students' knowledge of grammar as well as their vocabularies. The learners were able to identify the keyword to determine the proper topic of listening task and also to understand a variety of English accents

\section{Discussion}

Ismail et al (2012) argued that Reciprocal Teaching involved extensive modeling of the comprehension fostering for reading. Furthermore, Rahimi \& Sadeghi (2014) also defined that Reciprocal Teaching assisted learners to obtain richer understanding of text and were likely to enhance their skill to use the strategies in reading comprehension. Likewise, Reciprocal Teaching let learners identify the ideas and important information about the text (Palincsar \& Brown, 1989). The previous researches gave the theoretical framework for this research. It was undeniable that either the previous or the recent study focused on Reciprocal Teaching for learners' comprehension. Instead of similarity, the difference was also found out that previous researches were carried out to improve learners' reading skill; this study was conducted for overcoming listening barrier.

Field note of observation stated the process of learning activity in the first and third meeting run well and only a few learners experienced difficulties in vocabularies together with different range of accents. Verbal together with numerical data were required to evaluate the weaknesses happening in the first cycle. Verbal data included field note of observation and questionnaire while 
numerical was listening comprehension test. Three indicators were employed to overcome learners' barriers in effective listening. The first indicator was detecting the key word which required learners to find out the specific details for example the key words. Becoming aware of this fact assisted them to the essential point of effective listening. The mean score for detecting the key word was 72 . On the contrary, ten learners still reached the low score. The second indicator was recognition vocabularies and grammar. The mean score was 79. It was higher than the first indicator, and only five learner getting low score. The third indicator was discrimination among sounds. The average score for the indicator was 59 (more detail, see table 1)

Table 1. The Increase from Pre-Test to Post Test of Learners' Barriers to Listening

\begin{tabular}{|c|c|c|c|c|c|c|c|}
\hline \multirow{2}{*}{ No } & \multirow{2}{*}{$\begin{array}{c}\text { Elements of } \\
\text { Learners' Barriers }\end{array}$} & \multicolumn{2}{|c|}{ Total Answered } & \multirow{2}{*}{ Increase } & \multicolumn{2}{|c|}{ Percentage } & \multirow{2}{*}{ Increase } \\
\hline & & Pre-test & Post-test & & Pre-test & Post-test & \\
\hline 1 & $\begin{array}{l}\text { Detecting key } \\
\text { word }\end{array}$ & 33 & 72 & 39.6 & $33 \%$ & $73 \%$ & $40 \%$ \\
\hline 2 & $\begin{array}{l}\text { Recognizing } \\
\text { vocabularies and } \\
\text { grammar }\end{array}$ & 52 & 79 & 26.4 & $53 \%$ & $80 \%$ & $27 \%$ \\
\hline 3 & $\begin{array}{l}\text { Discriminating } \\
\text { among sounds }\end{array}$ & 26 & 59 & 33 & $26 \%$ & $60 \%$ & $34 \%$ \\
\hline
\end{tabular}

The table above showed the increase of pre-test along with post-test of cycle 1. Total correct answered from pre-test to post test a bit enhanced; it meant Reciprocal Teaching had been effective to assist learners' barriers to effective listening. The highest increase was in detecting key word (40\%) while the lowest enhancement was in recognition vocabularies and sounds (33\%). The increase of discrimination among sounds was (33\%). It occurred due to the successful method which let learners better in listening.

The field note of observation revealed that the classroom situation was concluded not as significant change. Some learners were neither willing to speak nor participate. When they were asked to answer some questions, they usually looked at their friends and were unwilling for standing up to answer the questions. The condition got worse because of fruitless activities in the class. Furthermore, some of them were still reluctant to take a part in activities planned the researcher. Hence, the class had been researcher's domination. The situation above let the researcher proceed the second cycle and revise the lesson plan effectively.

The first cycle result became the consideration of the second cycle. In this cycle, the learners' barriers relevant to listening were overcome and the listening activity ran as well. When researcher gave learners question such as:

What did Mr. X do if Mr. Y could not pick his up?

a. Booked a shuttle 
b. Reserved a shutter

c. Went to the dentist

What will Martha sell?
a. Diamond jewelry
b. Gold jewelry
c. Engagement rings

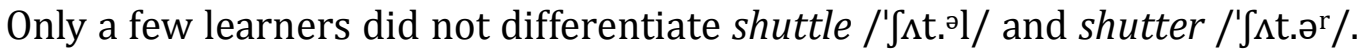
After Reciprocal Teaching implementation, learners were able to remember the different pronunciation between shutter and shuttle. In the next question, a few learners were not able to detect the specific word to obtain the information. Diamond jewelry, gold jewelry, and engagement rings were the things mentioned in the dialogue. Most of the learners answered gold jewelry, but the key word of the question was what will Martha sell? Having been trained using Reciprocal Teaching, they were able to detect the key word to answer the correct question. Here, class discussion occurred and democratic classroom atmosphere encouraged learner to be active in class.

Reciprocal Teaching needed some stages to implement (Peng, Wang, \& Effects, 2015). Summarizing let learners identify the ideas and important information about the text. Hence, the strategy could help learners determine the main idea of the text. Questioning provided a context to explore the text deeply and to assure the meaning construction. The strategy could assist learners advocate either implicit or explicit information from the text. Clarifying assisted learners to clarify difficult aspect about the text. Asking learners to clarify made them engage in critical evaluation which was confusing. Learners with low level of comprehension would be assisted by learners with higher comprehension. Predicting also helped learners obtain general idea using their background of knowledge. Through this strategy, learners made their hypotheses about the text. The enhancement of the test could be seen in this table below:

Table 2. The Increase from Post-Test 1 to Post Test 2 of Learners' Barriers to Listening

\begin{tabular}{|c|c|c|c|c|c|c|c|}
\hline \multirow[b]{2}{*}{ No } & \multirow{2}{*}{$\begin{array}{c}\text { Elements of } \\
\text { Learners' } \\
\text { Barriers }\end{array}$} & \multicolumn{2}{|c|}{ Total Answered } & \multirow[b]{2}{*}{ Increase } & \multicolumn{2}{|c|}{ Percentage } & \multirow[b]{2}{*}{ Increase } \\
\hline & & $\begin{array}{c}\text { Post-test } \\
1\end{array}$ & $\begin{array}{c}\text { Post-test } \\
2\end{array}$ & & $\begin{array}{c}\text { Post-test } \\
1\end{array}$ & $\begin{array}{c}\text { Post-test } \\
2\end{array}$ & \\
\hline 1 & $\begin{array}{l}\text { Detecting key } \\
\text { word }\end{array}$ & 72 & 79 & 6.6 & $73 \%$ & $80 \%$ & $6.7 \%$ \\
\hline 2 & $\begin{array}{l}\text { Recognizing } \\
\text { vocabularies } \\
\text { and grammar }\end{array}$ & 79 & 85 & 6.6 & $80 \%$ & $86 \%$ & $6.7 \%$ \\
\hline 3 & $\begin{array}{l}\text { Discriminating } \\
\text { among sounds }\end{array}$ & 59 & 79 & 19.8 & $60 \%$ & $80 \%$ & $20 \%$ \\
\hline
\end{tabular}


Based on the daily observation, it was found out that Reciprocal Teaching simply improved learners' class situation. During the research, learners came to the class on time. Concerning the activity in listening class, most of them participated actively; learners were encouraged to be supportive of and receptive to each other's communication during active listening. The class discussion got better and learners felt freedom to open up their ideas. The table shows the result of interview about the effect of Reciprocal Teaching in teaching learning process.

Table 3. Learners' Attitude on Learning Process

\begin{tabular}{c|l|c|c|c|c}
\hline No & \multicolumn{1}{|c|}{ Questions } & $\begin{array}{c}\text { Strongly } \\
\text { Agree }\end{array}$ & Agree & Disagree & $\begin{array}{c}\text { Strongly } \\
\text { Disagree }\end{array}$ \\
\hline 1 & $\begin{array}{l}\text { Listening Comprehension via } \\
\text { Reciprocal Teaching, I was more } \\
\text { self-directed }\end{array}$ & $23 \%$ & $72 \%$ & $3 \%$ & $2 \%$ \\
\hline 3 & $\begin{array}{l}\text { Listening Comprehension via } \\
\text { Reciprocal Teaching encouraged me } \\
\text { to work with my classmate due to } \\
\text { mutual project }\end{array}$ & 70 & 25 & 2 & 2 \\
\hline $\begin{array}{l}\text { Listening Comprehension via } \\
\text { Reciprocal Teaching brought fresh } \\
\text { class climate in learning }\end{array}$ & 69 & 23 & 6 & 2 \\
\hline $\begin{array}{l}\text { Listening Comprehension via } \\
\text { Reciprocal Teaching, I could } \\
\text { contribute the knowledge to } \\
\text { classmates quickly }\end{array}$ & 28 & 65 & 4 & 2 \\
\hline 5 & $\begin{array}{l}\text { Listening Comprehension via } \\
\text { Reciprocal Teaching was } \\
\text { appropriate for student-centered } \\
\text { learning 26 }\end{array}$ & 66 & 5 & 3 \\
\hline
\end{tabular}

Having identified the fact about teaching learning process, the researcher was convinced that learners' barriers to effective listening could be solved by implementing Reciprocal Teaching. Reciprocal Teaching had significantly positive impact on listening comprehension. Learners used kinds of Reciprocal Teaching strategy and knew what, why, and how to use it (AlSaraireh \& Hamid, 2016). It stimulated them for planning, monitoring, and evaluating their listening. These finding also had pedagogical implication for Reciprocal Teaching; it affected essential improvement on learners' participation in class. It also provided effective work collaboratively in group discussion to optimize their listening comprehension. Thus, learners' self-regulatory and monitoring skill could be improved 


\section{Conclusion}

In relation to the research finding and discussion, the exploration of Reciprocal Teaching can overcome learners' barriers to effective listening. The enhancement is represented by the increase of mean score in post-test cycle 1 and cycle 2. Learners are able to detect key words, recognize vocabularies and grammar, and also discriminate among sounds. In addition, Reciprocal Teaching can affect the teaching learning process. Learners' attention to the class gets better; their participation to involve in group discussion to overcome the listening barriers enhances. Moreover, learners are encouraged to be receptive to each other's communication during active listening.

These findings of the research have pedagogical implication for Reciprocal Teaching. The appropriate choice of method or technique will give good impact in both process and result of the teaching and learning itself. Reciprocal Teaching also appears to build more significant effects for learners as reflected for improving academic achievement. It also facilitates learners in order to comprehend the real language and assists them to communicate in real conversation. Thus, employing Reciprocal Teaching makes the listening text more comprehensible.

Employing Reciprocal Teaching also affects significantly positive teaching learning process. Somehow, Reciprocal Teaching is not the only thing which solves learners' difficulty in listening comprehension. It has to be supported by the other factors including lecturers' role during the class and learners' activeness to catch up the better result of listening comprehension. Before Reciprocal Teaching implementation, it is suggested that lectures have to make sure that learners have already understood how to apply it. Lecturers should produce enjoyable learning activity, so they will have plenty opportunities for exploring their ideas and deriving the knowledge. It was expected to other researchers that the result of this study can be utilized as additional reference for further research to create a better learning. They should also do the research further to find out the weakness which still occurs

\section{References}

AlSaraireh, M. Y. A., \& Hamid, K. M. N. K. (2016). The Effect of the Reciprocal Teaching Model on Developing Jordanian Students' Reading Comprehension at Mutah University. International Journal of Linguistics, 8(6), 69. https://doi.org/10.5296/ijl.v8i6.10448

Hopkins, D. (1993). Teacher's Guide to Classroom Research. Great Buckingham: Open University Press.

Hui S, B. L., \& Gunarso Susilohadi, Mp. (2011). Legitimation From the Board of Examiners Improving Students' Speaking Skill Through Content -Based Intruction. 
Ismail, H. N., Ahmadi, M. R., \& Gilakjani, A. P. (2012). The role of reciprocal teaching strategy as an important factor of improving reading motivation. Elixir International Journal, 53(December 2012), 11836-11841.

Lestari, Sukirlan, G. (2016). Increasing Students 'Micro Skills of Listening through Drills at the Second Year Students Tri Lestari

Masruddin, M. (2018). Preparation and Strategies Applied by Teachers of Math And Science in English of Bilingual Program at Elementary School. IDEAS: Journal on English Language Teaching and Learning, Linguistics and Literature, 2(1). doi:https://doi.org/10.24256/ideas.v2i1.133

Palincsar, A.S., \& Brown, A.L. (1989). Reciprocal Teaching activities to promote Reading with your mind. Newyork: The College Boar

Peng, T., Wang, S., \& Effects, S. (2015). Effects of Reciprocal Teaching on EFL Fifth Graders' English Reading Ability. International Journal of Contemporary Educational Research, 2(2), 76-88-88.

Picard, M., \& Velautham, L. (2016). Developing Independent Listening Skills for English as an Additional Language Students. International Journal of Teaching and Learning in Higher Education, 28(1), 52-65. Retrieved from http://www.isetl.org/ijtlhe/

Rahimi, M., \& Sadeghi, N. (2014). Impact of reciprocal teaching on EFL learners' reading comprehension. Research in Applied Linguistics, 6(1), 64-86.

Rodli, M., \& Prastyo, H. (2017). Applying Reciprocal Teaching Method in Teaching Reading. Studies in Linguistics and Literature, 1(2), 112. https://doi.org/10.22158/sll.v1n2p112

Sukmawati, P., \& Eka, M. (2018). Listen English Full Audio as a Supporting Media in Improving Students' Listening Skill. IDEAS: Journal on English Language Teaching and Learning, Linguistics and Literature, 6(2). doi:https://doi.org/10.24256/ideas.v6i2.507

Tamura, E. T. (2006). Concepts on the methodology of teaching English. The Economic Journal of Takasaki City University of Economics, 48(3), 169-168. 